\title{
FREQUENCY OF ABO AND RHESUS (D) BLOOD GROUPS IN TRIBAL POPULATION OF MADHYA PRADESH: A STUDY FROM TERTIARY CARE TEACHING HOSPITAL IN MADHYA PRADESH
}

Ajit Saluja1, Dolly Sharma²

\section{HOW TO CITE THIS ARTICLE:}

Ajit Saluja, Dolly Sharma. "Frequency of ABO and Rhesus (D) Blood Groups in Tribal Population of Madhya Pradesh: A Study from Tertiary Care Teaching Hospital in Madhya Pradesh". Journal of Evolution of Medical and Dental Sciences 2015; Vol. 4, Issue 32, April 20; Page: 5538-5544, DOI: 10.14260/jemds/2015/810

ABSTRACT: BACKGROUND: ABO and Rh blood groups are most important blood groups in human beings. The frequency of four main blood group systems varies in population throughout the world and even in different parts of country. Objective if this study was to identify distribution of ABO and $\mathrm{Rh}$ blood group system. MATERIALS AND METHODS: Blood samples from 10680 tribals were collected in Jhabua district of Madhya Pradesh during the month of June 2012. Among 10680 tribals, 5670 were male. Blood groups were done in tribals belonging to Bhil, Bhilala \& Katthiwar tribes. For the blood grouping of the patients, $5 \mathrm{cc}$ of clotted blood was collected \& transported to Department Pathology, Peoples College of medical sciences, Bhopal. RESULTS: A total 10680 samples were analyzed, out of which 5670 (53\%) samples were of male. The frequency of blood group B in our population was $36.9 \%$; $=3950$ (35.37\% B Rh positive and $1.61 \% \mathrm{~B}$ Rh negative) and frequency of blood group B remain highest in our study group. The frequency of blood group 0 in our population was 31.8\%; $\mathrm{n}=3400$ (30.43\% $\mathrm{O} \mathrm{Rh}$ positive and 1.4\% $\mathrm{O}$ Rh negative) followed by blood group A was 24.3\%; $n=2600$ (23.15\% A Rh positive and 1.18\% A Rh negative) and blood group AB was 6.8\%; $\mathrm{n}=730(6.63 \% \mathrm{AB}$ Rh positive and $0.2 \% \mathrm{AB}$ Rh negative) The overall phenotypic frequencies of $\mathrm{ABO}$ blood groups were $B>0>A>A B$. Rh (D) positive were 95.59\%; $n=10210$ and $R h$ (D) negative were 4.41\%; $n=470$. DISCUSSION: B positive blood group is significantly high in our population. Every transfusion center should have a record of frequency of blood group system in their population. It helps in inventory management. Knowledge of blood group distribution is important for clinical studies, for reliable geographical information and for forensic studies in the population.

KEYWORDS: Blood group, ABO Blood group, Rh (D) Blood group, Tribals.

INTRODUCTION: Since 1901, more than 20 distinct blood group systems have been identified but the $\mathrm{ABO}$ and Rhesus (Rh) blood groups remain clinically most important. Furthermore, they are also well-defined genetic markers employed in population genetic and anthropological studies. ${ }^{1,2}$ Karl Landsteiner in 1901 discovered the first human blood group, which was the ABO group. ${ }^{3}$ Landsteiner and Wiener defined later Rh blood group in 1941.4 Together these two systems have proved to be the most important for blood transfusion purposes. In modern medicine, the need for blood group frequency and prevalence studies is multipurpose, as besides their importance in evolution, their relation to disease and environment is being increasingly important.5,6 Besides being important in relation to blood transfusion and organ transplantation, blood group antigens can also be utilized in genetic research, forensic pathology and anthropology and training ancestral relation of human. ${ }^{7}$ Blood groups are genetically inherited. Frequency of blood groups varies from race to race one country to another and even different regions of a country. The aim of this study was to find frequency of $\mathrm{ABO} \&$ Rhesus blood groups of Tribal individuals from Madhya Pradesh. 


\section{ORIGINAL ARTICLE}

MATERIAL \& METHODS: Blood samples from 10680 tribals were collected in Jhabua district of Madhya Pradesh during the month of June 2012. Among 10680 tribals, 5670 were male. Blood groups were done in tribals belonging to Bhil, Bhilala \& Katthiwar tribes. For the blood grouping of the patients, $5 \mathrm{cc}$ of clotted blood was collected \& transported to Department Pathology, Peoples College of medical sciences, Bhopal. The blood samples were collected by venipuncture in EDTA containing vacutainer. $\mathrm{ABO}$ and $\mathrm{Rh}$ blood grouping were done by agglutination test using anti-A, anti-B and anti$\mathrm{D}$ human sera. Blood group (ABO) and Rhesus factor was done by the antigen antibody agglutination test.

STATISTICAL ANALYSIS: Frequency, percentage and proportions for each variable were calculated and $95 \%$ confidence interval (CI) was taken to define normal range.

RESULT: A total 10680 samples were analyzed, out of which 5670 (53\%) samples were of male. The frequency of blood group B in our population was $36.9 \%$; $=3950$ (35.37\% B Rh positive and $1.61 \%$ $\mathrm{B}$ Rh negative) and frequency of blood group B remain highest in our study group. The frequency of blood group $\mathrm{O}$ in our population was 31.8\%; $\mathrm{n}=3400$ (30.43\% $\mathrm{O} \mathrm{Rh}$ positive and $1.4 \% \mathrm{O} \mathrm{Rh}$ negative) followed by blood group A was 24.3\%; $\mathrm{n}=2600$ (23.15\% A Rh positive and $1.18 \% \mathrm{~A}$ Rh negative) and blood group $\mathrm{AB}$ was 6.8\%; $\mathrm{n}=730$ (6.63\% $\mathrm{AB} \mathrm{Rh}$ positive and $0.2 \% \mathrm{AB} \mathrm{Rh}$ negative). The overall phenotypic frequencies of $A B O$ blood groups were $B>0>A>A B$. Rh (D) positive were 95.59\%; $\mathrm{n}=10210$ and $\mathrm{Rh}(\mathrm{D})$ negative were 4.41\%; n=470. [Table I \& II] [Figure 1, 2 \& 3].

\begin{tabular}{|c|c|c|c|}
\hline Blood Groups & Total Study Subjects & Prevalence & Confidence limit (95\%) \\
\hline \multicolumn{4}{|c|}{ ABO Blood Group } \\
\hline A & 2600 & 24.34 & $23.53-25.15$ \\
\hline B & 3950 & 36.99 & $36.07-37.91$ \\
\hline AB & 730 & 6.83 & $6.35-7.31$ \\
\hline O & 3400 & 31.83 & $30.95-32.71$ \\
\hline \multicolumn{4}{|c|}{ Rhesus (D) Blood Group } \\
\hline Rh positive & 10210 & 95.59 & $95.20-95.58$ \\
\hline Rh negetive & 470 & 4.41 & $4.02-4.80$ \\
\hline \multicolumn{3}{|c|}{ Table I: Frequency of ABO \& Rh blood group systems } \\
\hline
\end{tabular}

\begin{tabular}{|c|c|c|c|}
\hline Blood Groups & Total Study Subjects & Prevalence & Confidence limit (95\%) \\
\hline A positive & 2473 & 23.15 & $22.35-23.45$ \\
\hline B positive & 3778 & 35.37 & $34.46-36.28$ \\
\hline AB positive & 709 & 6.63 & $6.16-7.10$ \\
\hline O positive & 3250 & 30.43 & $29.56-31.30$ \\
\hline A negative & 127 & 1.18 & $0.98-1.38$ \\
\hline B negative & 172 & 1.61 & $1.37-1.85$ \\
\hline AB negative & 21 & 0.2 & $0.12-0.28$ \\
\hline O negative & 150 & 1.4 & $1.18-1.62$ \\
\hline
\end{tabular}

Table II: Distribution of ABO and Rhesus (D) blood group among study population $(n=10,680)$ 


\section{ORIGINAL ARTICLE}

The caste wise distribution was as follows, Among Bhils, 1254 individuals had B group followed by 0, A \& AB with 1199, 1125 and 194 individuals respectively. In Bhilalas, Highest number was with B group with 1457 individuals while $O$ and $A$ was with nearly equal frequency of 1337 and 1291 individuals and AB in 240 individuals. In Katthiwars, B and A groups constituted the majority with 930 and 904 cases each. 0 group was positive in 600 individuals followed by 149 subjects with AB group. [Table III][Figure 4].

\begin{tabular}{|c|c|c|c|c|c|c|c|}
\hline Caste & A & B & AB & O & Rh positive & Rh negative & Total \\
\hline Bhil & 1125 & 1254 & 194 & 1199 & 3614 & 158 & $\mathbf{3 7 7 2}$ \\
\hline Bhilala & 1291 & 1457 & 240 & 1337 & 4130 & 195 & $\mathbf{4 3 2 5}$ \\
\hline Khattiwar & 904 & 930 & 149 & 600 & 2466 & 117 & $\mathbf{2 5 8 3}$ \\
\hline \multicolumn{1}{|c|}{ Table III: Caste wise distribution of ABO and Rh blood group } \\
\hline
\end{tabular}

\section{Frequency of ABO blood group}

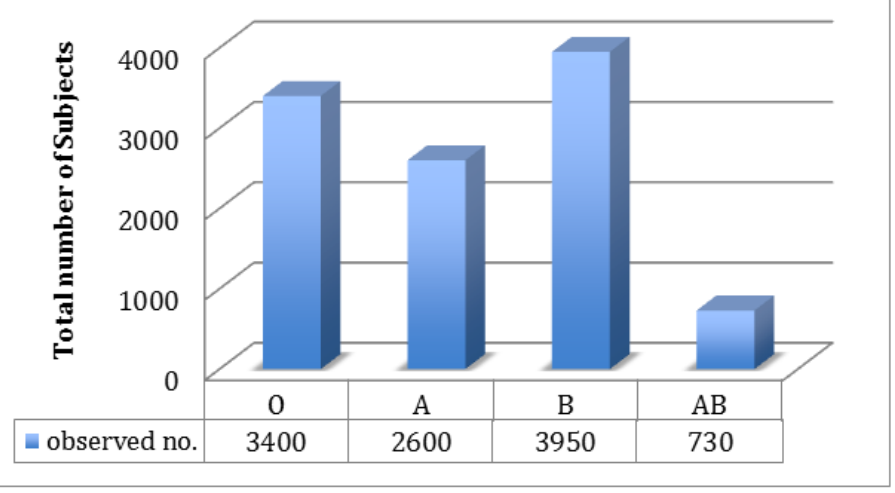

\section{Figure 1: Distribution of ABO blood group}

\section{Frequency of Rh (D) blood group}

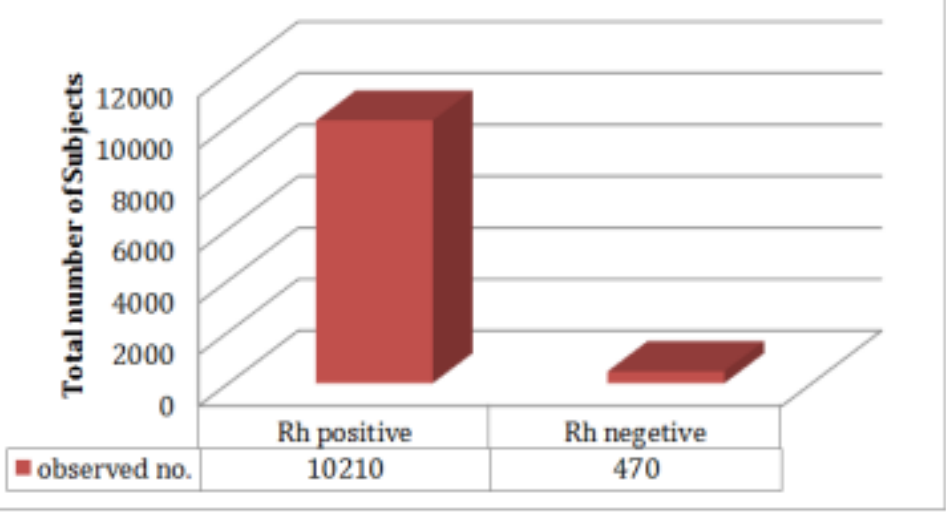

Figure 2: Frequency of Rhesus (D) blood group 


\section{ORIGINAL ARTICLE}

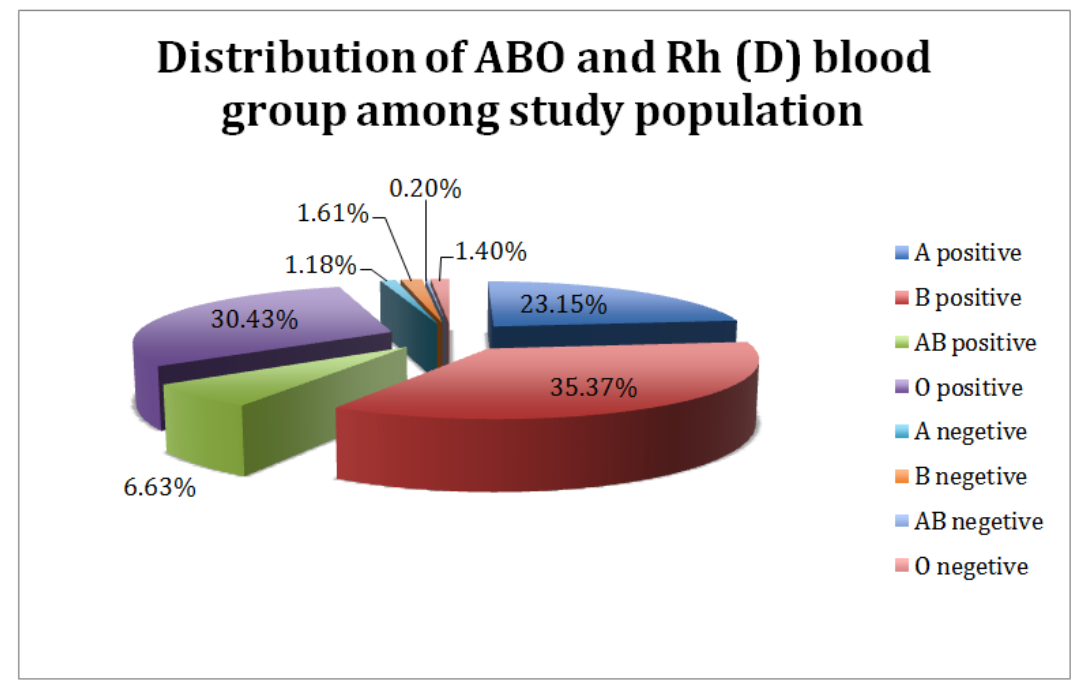

Figure 3: Prevalence of ABO and Rhesus (D) blood groups among study population

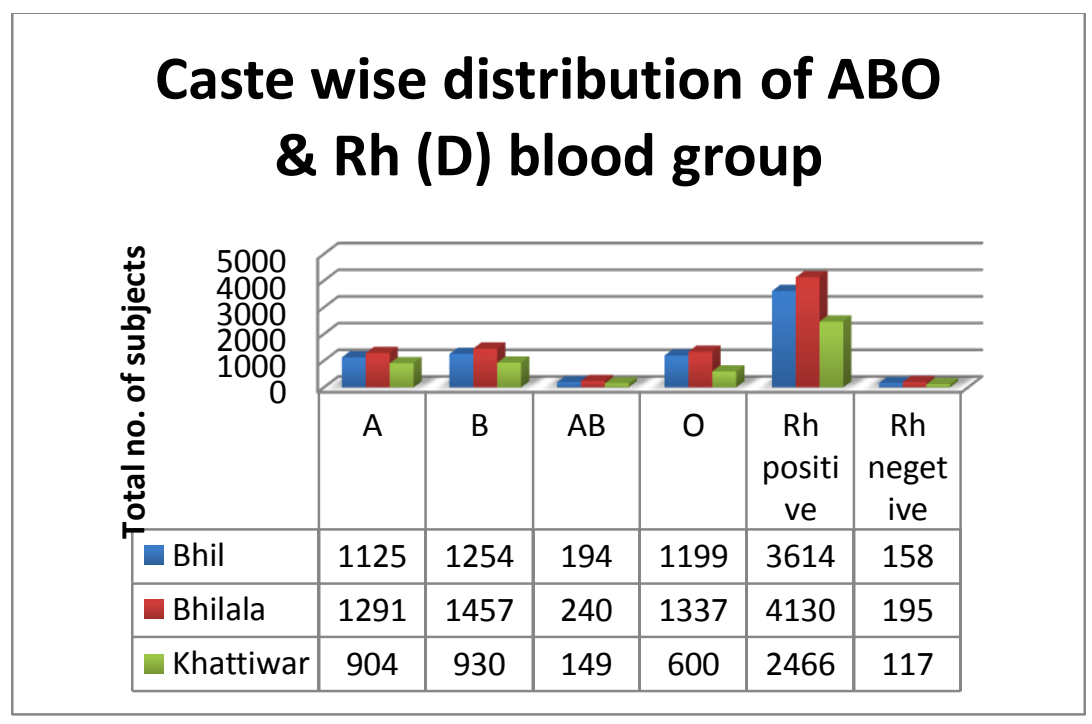

\section{Figure 4: Caste wise distribution of $\mathrm{ABO}$ and $\mathrm{Rh}$ (D) blood group among study population}

DISCUSSION: Blood groups and Rh antigen are hereditary. Gene for ABO antigens is on the 9th chromosome and $\mathrm{Rh}$ antigen gene is on the 1st chromosome. ${ }^{8}$ The distribution of ABO blood group varies regionally, ethically and from one population to another. In the present study, the ABO blood group typing in the total sample showed the same trend of prevalence as in the general Indian subcontinent $(B \geq 0>A>A B)$. The study of distribution of blood groups is important as it plays a vital role in blood transfusion, organ transplantation, genetics research, human evolution, forensic pathology and some groups have shown associations with diseases like duodenal ulcer, diabetes mellitus, urinary tract infection and $\mathrm{Rh}$ and $\mathrm{ABO}$ incompatibilities of newborn. 


\section{ORIGINAL ARTICLE}

We compared our result with other studies carried out in different part of our country [Table IV], The studies done in North India by Nanu et al, ${ }^{9}$ in parts of Rajasthan by Behra et al ${ }^{10}$ and other comparatively northern and central part of India like Indore, Punjab, Maharashtra showed blood group B is the commonest followed by $\mathrm{O}, \mathrm{A}$ and $\mathrm{AB}$. The similar kinds of result were found in our study. But study carried out in Kashmir by Latoo JA ${ }^{11}$ et al showed that 0 blood group is more common followed by $\mathrm{B}$ followed by $\mathrm{A}$ and $\mathrm{AB}$ respectively.

\begin{tabular}{|c|c|c|c|c|c|c|}
\hline Population & $\mathbf{A}$ & B & AB & $\mathbf{0}$ & Rh positive & Rh negative \\
\hline North India9 & 24.7 & 37.5 & 5.3 & 32.5 & 95.37 & 4.63 \\
\hline Kashmir 11 & 22.95 & 32.05 & 6.55 & 38.43 & 95.92 & 4.08 \\
\hline Western Rajasthan 10 & 22.2 & 36.4 & 9.4 & 31.7 & 91.75 & 8.25 \\
\hline Jhalwar, Rajasthan 12 & 25.02 & 31.76 & 10.4 & 32.8 & 93.4 & 6.6 \\
\hline Tripura 13 & 23.77 & 32.8 & 9.64 & 32.75 & 97.06 & 2.94 \\
\hline Maharashtra14 & 23.38 & 31.89 & 8.72 & 30.99 & 95.36 & 4.64 \\
\hline Indore 15 & 24.15 & 32.25 & 9.1 & 31.5 & 95.43 & 4.57 \\
\hline punjab16 & 21.91 & 37.56 & 9.3 & 31.23 & 97.3 & 2.3 \\
\hline lathur17 & 29.35 & 31.25 & 9.74 & 29.64 & 93.1 & 6.9 \\
\hline Hyderabad 18 & 19.57 & 34.11 & 5.76 & 40.54 & 95.37 & 4.63 \\
\hline Pondicherry 19 & 39.5 & 20.5 & 6.5 & 34 & 97 & 3 \\
\hline Banglore $^{20}$ & 23.85 & 29.95 & 6.37 & 39.82 & 94.2 & 5.8 \\
\hline Vellore $^{21}$ & 21.86 & 32.69 & 6.7 & 38.75 & 94.5 & 5.5 \\
\hline Dakshina Kannada 22 & 25.8 & 27.3 & 4.8 & 42 & 94.64 & 5.36 \\
\hline Thiruvananthapuram ${ }^{23}$ & 26.21 & 27.39 & 6.36 & 40.05 & 94.42 & 5.58 \\
\hline Present study & 24.34 & 36.99 & 6.83 & 31.83 & 95.59 & 4.41 \\
\hline
\end{tabular}

While studies carried out in comparatively Southern part of India by Swarajya Kumari Koran et $\mathrm{al}^{18}$ at Hyderabad, Subhashini $\mathrm{AB}$ et al ${ }^{19}$ at pondicherry, Periyavan et al at Bangalore, ${ }^{20}$ found that commonest blood group was $\mathrm{O}$ followed by $\mathrm{B}, \mathrm{A}$ and $\mathrm{AB}$. These results were not similar to the results of our studies.

Internationally, a study done in Pakistan ${ }^{24}$ showed that the frequency of blood group B > $0>$ A > AB while other studies ${ }^{25-29}$ showed 0 blood group to be the most prevalent.

The incidence of Rhesus (D) positive blood group in most of the part of India varies from 94\% to $98 \%$ and $2 \%$ to $6 \%$ were $\mathrm{Rh}$ negative. The present study results are within this range. These figures are similar to the other studies carried out in different part of India ${ }^{9-23} \mathrm{Rh}$-positive groups are predominant group and the frequency is more or less the same.

CONCLUSION: The frequency of ABO and Rh phenotypes in Tribal population appears to be similar to Asian data. The B blood group is significantly higher in our study population and comparatively low $\mathrm{AB}$ blood group. Generation of simple database of blood groups, not only provides data about the 
availability of human blood in case of regional calamities, but also serves to enable insight into possibilities of future burden of diseases. It is hoped that the data generated in this study would assist in the planning and establishment of a functional blood service that would meet the ever-increasing demand for safe blood and blood products. Hence this study is useful in providing information on the status of $\mathrm{ABO}$ and $\mathrm{Rh}$ blood group distribution in tribal population of Madhya Pradesh.

\section{REFERENCES:}

1. Amin-ud-Din $\mathrm{M}$ et al. Serological study among the municipal employees of Tehran, Iran. Distribution of ABO and Rh blood groups. Haematology, 2004, 7 (4): 502-4.

2. Sigmon JM. Basic principles of the $A B O$ and Rh blood group systems for hemapheresis practitioners. Journal of clinical apheresis, 1992, 7 (3): 158-62.

3. Garraty G, Dzik W, Issitt PD, Lubin DM, Reid ME, Zelinski T. Terminology for blood group antigens and genes-historical origins and guideline in the new millennium. Transfusion 2000; 40: 477-89.

4. Rahman M and Lodhi Y. Frequency of $\mathrm{ABO}$ and Rhesus blood groups in blood donors in Punjab. Pak J Med Sci 2004; 20: 315-8.

5. Groups and Rh factor in Bannu region NWFP (Pakistan). Pak J Med Res 2004; 43 (1): 8-10.

6. Khaliq MA, Khan JA, Shah H, Khan SP. Frequency of ABO and Rh (D) blood group in Hazara division (Abbottabad) . Pak J Med Res 1984; 23: 102-3.

7. Khurshid B, Naz M, Hassan M, Mabood SF. Frequency of ABO and Rh (D) blood groups in district Sawabi NWFP Pakistan. J Sci Tech Univ. Peshawar 1992; 16: 5-6.

8. Webert EK, Chan HW, Smith JW, Heddle NM, Kelton JG. Red cell, Platelet, and white cell antigens. In: Wintrobe's Clinical Hematology. Greer JP, Foerster J, Lukens JN, Rodgers GM, Paraskevas F, Glader B. Eleventh edition, Philadelphia, Lippincott Williams Wilkins, 2004: 791829.

9. Nanu A, Thapliyal RM. Blood group gene frequency in a selected north Indian population. Indian J Med Res 1997; 106: 242-6.

10. Behra Rajashree, Joshi Yogi Ray: National Journal of Medical Research, Distribution of ABO blood group and Rh (D) factor in Western Rajasthan.

11. Latoo JA, Masoodi NA, Bhat NA, Khan GQ, Kadla SA. The ABO and Rh blood groups in Kashmiri population. Indian J for the Practicing Doctor. 2005, 3 2: 2006-5-2006-6.

12. Manu Mathur, Rishi Diwan: A retrospective study of pattern and frequency of blood groups in voluntary donors attending blood bank of a teritiary care hospital. J of Pharmaceutical Sciences and Biomedical SciencesVol. 21, Issue, 2.

13. Dr Pranab chowdhary, Frequency and distribution of blood groups in blood donors of Tripura, The Health agenda, Volume 2 Issue 2 April, 2014.

14. Giri PA, Yadav S, Parhar GS, Phalke DB. Frequency of ABO and Rhesus blood groups: A study from a rural tertiary care teaching hospital in India. Int J Biol Med Res 2011; 2: 988-90.

15. Gupta Nrendra Kumar, Dadwal, S: Distribution of ABO and Rhesus blood groups: Asian J TransSci: 2012, Vol: 6, 1: 73.

16. Sidhu S. Distribution of the ABO blood groups and Rh (D) factor among the scheduled caste population of Punjab. Anthropologist 2003; 5: 203-4. 


\section{ORIGINAL ARTICLE}

17. Deshpande RH, Kolhe Shrish M: Distribution of blood groups in blood donors at Sri Saraswathi Karad Blood bank, Latur.

18. Koran S K, Sadhula M, Veldurthy V S, Distribution of ABO and RH - blood group in blood donors at teritiary care centre.

19. Subhashini $A B$, Distribution of $A B O$ and rhesus - D blood groups among Irulas, a tribal population of Pondicherry, India, Anthropologist, 2007: 9 (2): 163-164.

20. Periyavan A Sangeetha SK, Marimuthu P, B K Manjunath and DM Seema Distribution of ABO and rhesus - D blood groups in and around Bangalore. Asian Journal Transfusion Science, 2010, 4: 41.

21. Das PK, Nair SC, Harris VK, Rose D, Mammen JJ, Bose YN, et al. Distribution of ABO and Rh-D blood groups among blood donors in a tertiary care centre in South India. Trop Doct. 2001; 31: 47-8.

22. Chandrika Rao \& Jyaprakash Shetty, Frequency of ABO and Rhesus blood groups in Dakshina Kannada district of Karnataka - a study from rural tertiary care teaching hospital in South India, Nitte University Journal of Health Sciences.

23. Abhishek B, Maya devi S, Meena D, Usha KC. Distribution of ABO and Rhesus-D blood groups in and around Thiruvnthapuram. Kerala Med J 2011; 1: 28-9.

24. Rahman M and Lodhi Y. Frequency of ABO and Rhesus blood groups in blood donors in Punjab. Pak J Med Sci 2004; 20: 315-8.

25. Firkin F, Chesterman C, Penington D, Rush B. De Gruchy's Clinical haematology in medical practice. Blackwell Science Publisher, 5th Edition 2008; pp-475.

26. Frances TF. Blood groups (ABO groups). In: common Laboratory and diagnostic tests. 3rd Edition, Philadelphia: Lippincott, 2002; p. 19-5.

27. Mwangni J. Blood group distribution in an urban population of patient targeted blood donors. east Afr Med J 1999; 76: 615-8.

28. Loua A, Lamah MR, Haba NY, Camara M. Frequency of blood groups ABO and Rhesus D in the Guinea population. Tranfus Clin Biol 2007; 14: 435-9.

29. Bashwari LA, Al Mulhim AA, Ahmad MS, Ahmed MA. Frequency of ABO blood groups in Eastern region of Saudi Arabia. Saudi Med J 2001; 22: 1008-12.

\section{AUTHORS:}

1. Ajit Saluja

2. Dolly Sharma

\section{PARTICULARS OF CONTRIBUTORS:}

1. Associate Professor, Department of Pathology, People's College of Medical Science \& Research Centre, Bhopal.

2. PG Resident, Department of Pathology, People's College of Medical Science \& Research Centre, Bhopal.

FINANCIAL OR OTHER COMPETING INTERESTS: None
NAME ADDRESS EMAIL ID OF THE CORRESPONDING AUTHOR:

Dr. Dolly Sharma, PG Girls Hostel,

People's College of Medical Sciences, Bhanpur, Bhopal-462037.

E-mail: dr.dollysharma9@gmail.com

Date of Submission: 24/03/2015.

Date of Peer Review: 25/03/2015.

Date of Acceptance: 08/04/2015.

Date of Publishing: 20/04/2015. 